\title{
Membrane-Disrupting Peptide EP-100
}

National Cancer Institute

\section{Source}

National Cancer Institute. Membrane-Disrupting Peptide EP-100. NCI Thesaurus. Code C84860.

A water-soluble, positively charged fusion protein consisting of a luteinizing hormone releasing hormone $(\mathrm{LHRH})$ receptor-targeting ligand conjug ated to the membranedisrupting peptide CLIP 71 with membrane-disrupting and potential antineoplastic activities. The LHRH ligand moiety of membrane-disrupting peptide EP-100 specifically binds to LHRH receptors, which are upregulated on a variety of human cancer cell types. Subsequently, the positively charged CLIP 71 moiety of this agent interacts with the negatively charged membrane on the cancer cell surface, which may result in cell membrane disruption and cell lysis. 